\title{
Radon Exhalation rate of soil and indoor radon concentration of various places of Karbi Anglong District of Assam.
}

\author{
R. K. Kakati \\ Department of physics, Diphu Govt.College, Diphu-782462, Assam, India. \\ [Under Assam University, Silchar (A Central University)].
}

\begin{abstract}
In this paper we report our results on radon exhalation rate of soil as well as indoor radon concentration of a few places of Karbi Anglong District of Assam. The technique of passive method has been adopted using LR-115 (type-II) plastic detector. Significant variations in radon exhalation rate and indoor radon concentration have been observed for the studied locations. The minimum and maximum values of radon exhalation rate as found for the present investigation are $348.37 \pm 17.4 \mathrm{mBqm}^{-2} h^{-1}\left(10.52 \pm 0.52 \mathrm{mBqkg} \mathrm{g}^{-1} h^{-1}\right)$ and1864.2 $\pm 92.7 \mathrm{mBqm}^{-2} \mathrm{~h}^{-1}\left(56.29 \pm 2.8 \mathrm{mBqkg^{-1 }} h^{-1}\right)$. For indoor radon concentration the minimum and maximum values as found from this study are $81.26 \pm 4.06 \mathrm{Bqm}^{-3}$ and $277.78 \pm 13.89 \mathrm{Bqm}^{-3}$.
\end{abstract}

Keywords: Radon exhalation rate, Indoor radon concentration, LR-115, Plastic detector.

\section{Introduction}

Radon $\left({ }^{222} \mathrm{Rn}\right)$, Thoron $\left({ }^{220} \mathrm{Rn}\right)$ and actinon $\left({ }^{219} \mathrm{Rn}\right)$ are the radionuclides that are found in the gaseous form in the decay series of Uranium and Thorium. Due to low abundance of parent nucleus U-235 and short half-life, actinon is believed to be not a significant contributor to the total radiation dose received by the population. Vast difference of half-lives of radon $(3.8 \mathrm{~d})$ and thoron $(55 \mathrm{sec})$ is a crucial parameter governing their release from ground and subsequent distribution to free atmosphere. It is believed that inhalation dose to the general population from thoron and its progeny is only about $10 \%$ (or little more) of the inhalation dose due to radon [1].

Inhalation of indoor radon $\left({ }^{222} \mathrm{Rn}\right)$ and its daughter product contribute a major fraction of total dose to human being from all possible sources of natural radioactivity.

Radon $\left({ }^{222} \mathrm{Rn}\right)$ being a daughter product of Uranium-238 series further decays to ${ }^{218} \mathrm{Po}(\mathrm{RaA}, 3.05 \mathrm{~min})$, ${ }^{214} \mathrm{~Pb}$ (RaB, $\left.26.8 \mathrm{~min}\right),{ }^{214} \mathrm{Bi}(\mathrm{RaC}, 19.7 \mathrm{~min}){ }^{210} \mathrm{~Pb}$ (RaD, 22.3 years) etc. Radon is chemically inactive and does not bind to tissues, upon inhalation the radon daughter like ${ }^{218} \mathrm{Po},{ }^{214} \mathrm{~Pb}$ irradiates the lungs tissues by $\alpha$ particles respectively with energies $6.0 \mathrm{Mev}$ and $8.7 \mathrm{Mev}$. Such $\alpha$-exposure is supposed to be one of the serious causes of increased incidence of lung cancer, skin cancer etc. [2].

Due to the existence of pressure difference between the soil and the indoor air, the transportation of radon from the underlying soil into the indoor air takes place by diffusion and / or with gases like $\mathrm{CO}_{2}$ and $\mathrm{CH}_{4}$ or water moving into the soil.

The concentration of radon and its progeny in the indoor air depends upon a number of parameter one of which is their exhalation rate, i.e., the amount of activity per unit area of the surface per unit time from soil and building materials to air. The typical values of exhalation rate for radon in soil and building materials are 0.02 and $0.05 \times 10^{-2} \mathrm{Bqm}^{-2} \mathrm{~s}^{-1}$ respectively.

Karbi Anglong district of Assam is one of the most geographically remote hilly district of Assam that is sharing its boarder with the state of Meghalaya. The global position of Karbi Anglong district is - latitudinal extension $25^{\circ} 32^{\prime}$ North - $26^{0} 33^{\prime}$ North and longitudinal extension $92^{\circ} 09^{\prime}$ East - $93^{\circ} 52^{\prime}$ East. The district is believed to be situated over zones of structural weakness as is evident from existence of a number of hot fluid channels (hot water springs) at different parts of the district.

In this work we have made an attempt to find indoor radon concentration in the dwellings and the radon exhalation rate of soils of few places of Karbi Anglong District of Assam and hence to find out the possible correlation between the indoor radon level and radon exhalation rate. The result of such studies may also provide some guiding information in regards to the possibility of exploration of uranium in this region.

\subsection{For the measurement of indoor radon}

\section{Experimental Procedure}

LR-115 (type-II) plastic detector obtained from Kodak Pathe was exposed for the measurement of indoor radon using plastic twin chamber dosimeter cups (BARC type). The exposure was done in three different modes (i) bare mode (ii) cup with filter paper and (iii) cup with filter paper-Mylar-filter paper [3]. 
The bare mode registered tracks due to total $\alpha$-activity, the detector facing the filter paper only registered tracks resulting from the decay of radon and thoron and the detector facing filter paper-Mylar-filter paper had registered the tracks of $\alpha$-particles due to the decay of radon.

For the present investigation the exposure was done for a period of 90 days (Jan - Mar.) in some selected Assam Type (AT) houses of various places of Karbi Anglong district of Assam. The cups were placed at least $1 \mathrm{~m}$ above the ground level and $15 \mathrm{~cm}$ away from the nearest wall or roof. Two AT houses were selected at each place for indoor Radon studies.

The detectors were retrieved and etched in $2.5 \mathrm{~N} \mathrm{NaOH}$ solutions at $60^{\circ} \mathrm{C}$ for a period of 90 minutes. For uniform etching, we have used a Remi magnetic stirrer and the tracks were then counted using a Spark counter.

The radon concentration is determined as [4]

Where $\quad \begin{aligned} C_{R}= & T_{1} / d \cdot K_{R} \\ C_{R} & =\text { concentration of radon in } B q / \mathrm{m}^{3} \text {. }\end{aligned}$

$\mathrm{T}_{1} \quad=$ Track density recorded in the membrane modes of exposure.

$\mathrm{d} \quad=$ No. of exposure days.

$\mathrm{K}_{\mathrm{R}} \quad=0.020 \mathrm{Tcm}^{-2} /$ Bq.d. $\mathrm{m}^{-3}$ is the sensitivity factor for radon in the membrane compartment.

\subsection{For the measurement of Radon exhalation rate in soil samples}

For the measurement of radon exhalation rate in soil samples we have used the same "Can technique method" adopted by Abu Jarad and khan et. al. [5, 6].

The collected soil samples were dried, powdered and kept inside the sealed bottles for a period of 30 days to obtain the equilibrium radon concentration inside the chamber. The detectors were then exposed to register $\alpha$-particle tracks due to decay of radon and left undisturbed for a period of 90 days.

The detectors were then etched and tracks were analyzed under the similar conditions used for indoor radon estimation.

The radon exhalation rate in terms of area is obtained from the expression [7]

$$
\mathrm{E}_{\mathrm{A}}=\frac{C V \lambda}{A\left[T+\frac{1}{\lambda}\{\operatorname{EXP}(-\lambda T)-1\}\right]}
$$

Where $\mathrm{E}_{\mathrm{A}}$ is radon exhalation rate in terms of area $\left(\mathrm{Bq} \mathrm{m}^{-2} \mathrm{hr}^{-1}\right)$; $\mathrm{C}$ the integrated radon exposure as measured by LR-115 plastic track detector $\left(\mathrm{Bq} \mathrm{m}^{-3} . \mathrm{hr}\right), \mathrm{V}$ the effective volume of the can $\left(\mathrm{m}^{3}\right), \lambda$ the decay constant for radon $\left(\mathrm{hr}^{-1}\right)$, $\mathrm{T}$ the exposure time $(\mathrm{hr})$, A the area of the can $\left(\mathrm{m}^{2}\right)$. The modified formulas to calculate the radon exhalation rate in terms of mass is $[8,9]$

$$
\mathrm{E}_{\mathrm{M}}=\frac{C V \lambda}{M\left[T+\frac{1}{\lambda}\{E X P(-\lambda T)-1\}\right]}
$$

Where $\mathrm{E}_{\mathrm{M}}$ is radon exhalation rate in terms of $\left(\mathrm{Bq} \mathrm{Kg}^{-1} \mathrm{hr}^{-1}\right)$ and $\mathrm{M}$ is the mass the soil sample (250gm).

\section{Figures And Tables}

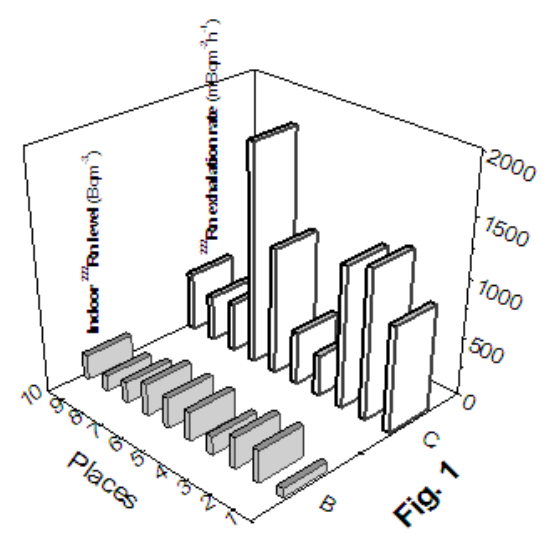

Fig. 1: Variation of ${ }^{222} \mathrm{Rn}$ exhalation rate of soil and indoor ${ }^{222} \mathrm{Rn}$ level of some selective places of Karbi Anglong district of Assam. 


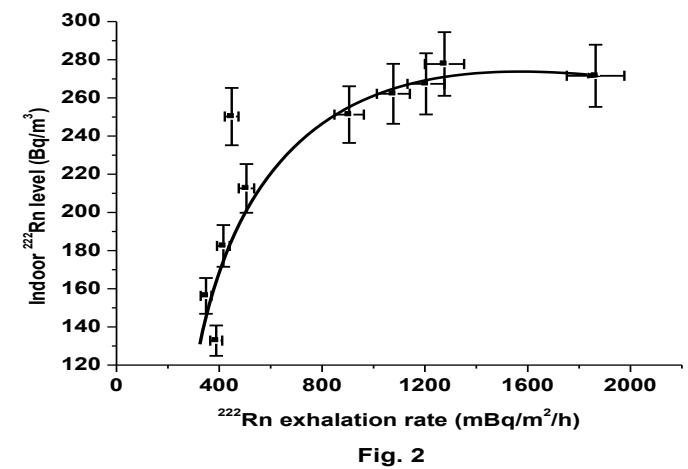

Fig. 2: Correlation of exhalation rate of soil and indoor ${ }^{222} \mathrm{Rn}$ level

Table - 1: Radon exhalation rate of soil and indoor radon level of different places of Karbi Anglong district of Assam.

\begin{tabular}{|c|c|c|c|c|}
\hline \multirow[t]{2}{*}{ S1. No. } & \multirow[t]{2}{*}{ Name of places } & \multicolumn{2}{|c|}{ Radon Exhalation rate } & \multirow{2}{*}{$\begin{array}{l}\text { Avg.Indoor radon level } \\
\left(\mathrm{Bq} / \mathrm{m}^{3}\right)\end{array}$} \\
\hline & & $\mathrm{E}_{\mathrm{A}}\left(\mathrm{mBqm}^{-2} \mathrm{~h}^{-1}\right)$ & $\mathrm{E}_{\mathrm{M}}\left(\mathrm{mBqkg}^{-1} \mathrm{~h}^{-1}\right)$ & \\
\hline 1. & Langsoliet & $905.33 \pm 48.06$ & $27.34 \pm 1.45$ & $81.26 \pm 4.06$ \\
\hline 2. & Mongjang & $1276 \pm 63.95$ & $38.54 \pm 1.93$ & $277.78 \pm 13.89$ \\
\hline 3. & P. Taijal & $1204.2 \pm 60.34$ & $36.36 \pm 1.82$ & $267.36 \pm 13.36$ \\
\hline 4. & Manja & $348.37 \pm 17.4$ & $10.52 \pm 0.52$ & $156.28 \pm 7.81$ \\
\hline 5. & Mohendijua & $448.05 \pm 22.4$ & $13.53 \pm 0.67$ & $250.24 \pm 12.51$ \\
\hline 6. & Longnit & $1077.26 \pm 53.86$ & $32.53 \pm 1.62$ & $262.15 \pm 13.10$ \\
\hline 7. & Hojaipur & $1864.2 \pm 92.7$ & $56.29 \pm 2.8$ & $271.60 \pm 13.58$ \\
\hline 8. & Kheroni & $415.62 \pm 20.8$ & $12.55 \pm 0.62$ & $182.45 \pm 9.12$ \\
\hline 9. & Diphu (Mentila) & $387.85 \pm 19.4$ & $11.76 \pm 0.58$ & $132.83 \pm 6.64$ \\
\hline 10. & Chutianala & $505.52 \pm 25.33$ & $15.26 \pm 0.76$ & $212.59 \pm 10.62$ \\
\hline
\end{tabular}

\section{Results And Discussions}

The values of radon exhalation rate of soil samples and indoor radon concentration of different places of Karbi Anglong District of Assam is shown in figure 1. The observed values are also listed in table 1. Figure 1 shows an increased value of indoor radon level at most of the places where the exhalation rates are also found to be relatively large.

Radon exhalation rates are found to vary from $348.37 \pm 17.4 \mathrm{mBqm}^{-2} \mathrm{~h}^{-1}\left(10.52 \pm 0.52 \mathrm{mBqkg}^{-1} \mathrm{~h}^{-1}\right)$ at Manja to $1864.2 \pm 92.7 \mathrm{mBqm}^{-2} \mathrm{~h}^{-1}\left(56.3 \pm 2.8 \mathrm{mBqkg}^{-1} \mathrm{~h}^{-1}\right)$ at Hojaipur. The indoor radon concentration, on the other hand, varies from $81.26 \pm 4.06 \mathrm{~Bq} / \mathrm{m}^{3}$ at Langsoliet to $277.78 \pm 13.89 \mathrm{~Bq} / \mathrm{m}^{3}$ at Mongjang with the average value equal to $209.50 \pm 10.20 \mathrm{Bqm}^{-3}$. The observed exhalation rate is much higher than the typical value which is $0.02 \mathrm{Bqm}^{-2} \mathrm{~s}^{-1}[1]$. The observed exhalation rates are about $5-26$ times larger than the typical value of exhalation rate of radon in soil.

When the average value of indoor radon of our case is compared with the indoor radon level in the same type of dwellings (AT Type) of the hilly regions surrounding Guwahati, Assam [10], it is found that average value of the present investigation is about twice the value reported for the dwellings surrounding Guwahati. It is observed that the indoor radon concentrations are higher than the global average value of 40 Bq. $\mathrm{m}^{-3}$ in all the studied locations [11].

To find the correlation between the observed exhalation rate and the concentration of indoor radon, in fig.2, we plot indoor radon concentration against exhalation rate. It is readily seen from this figure that with the increase of radon exhalation rate of soil of the studied sites, the indoor radon concentration increases almost linearly and then attains a saturation value. That is, further increase of exhalation rate cannot influence the indoor radon concentration indicating towards a dynamical equilibrium in indoor radon level. However to find an analytical relationship, if any, between the two, we have to increase our sample size in regards to the number of studied sites as well as the number of dwellings studied per site. And also the observation on indoor radon concentration should be made for all the seasons of a year.

\section{Conclusion}

From the above studies it can be concluded that indoor radon depends upon the radon exhalation rate of soil and with increase in radon exhalation rate of soil, the indoor radon concentration also increases and attains a saturation value. Further, similar observations will have to be done in different locations to come to a final conclusion. 


\section{Acknowledgements.}

The author acknowledges with gratitude for the guidance of Dr. B. Bhattacharjee, Professor, Department of Physics, Gauhati University, Guwahati, Assam, India and highly thankful to Dr. T.V.Ramachandran, Ex-Scientist, Bhaba Atomic Research Center, Mumbai, India for helpful discussion for carrying out this research work.

\section{References}

[1]. BARC Report (2003): No.BARC/2003/E/026, pp.1-43

[2]. Sen, M., Mishra, R., Tripathy, S. P., Sinha, D., Kulshreshtha, A., Dwivedi, K.K., Deka, P. C., and Bhattacharjee, B., (1998). J. Assam Sci. Sco., 39(3), 105- 116.

[3]. Dwivedi, K. K., Mishra, R., Tripathy, S. P., Kulshreshtha, A., Sinha, D., Srivastava, A., Deka, P., Bhattacharjee, B., Ramachandran, T.V.and Nambi, K.S.V., (2001). Radiation Measurement 33, 7-11.

[4]. Eappen,K.P., Mayya, Y.S., Calibration factors for LR-115(Type-II) based radon thoron discriminating dosimeter ,Vol.38, issue 1,(2004), Radiation Measurement pp.5-17.

[5]. Abu-Jarad F, 1988, Applications of nuclear track detectors for radon related measurements, Nuclear Track Radiation Measurement, 15, 525

[6]. Khan, A. J., Prasad, R.and Tyagi, R.K. (1992) "Measurement of Radon Exhalation rate from some building materials", Nuclear Track Radiation Measurement, 20, pp.609-610.

[7]. Singh, Joga., Singh, Harmanjit., Singh, Surinder and Bajwa, B S, (2009), Uranium, radium and radon exhalation studies in some soil samples using plastic track detectors, Indian J.Physics 83(8) pp 1147-1153.

[8]. Sharma, D. K., Kumar, A., Kumar, M. and Singh, S., (2003), Radiation Measurements, Vol. 36,pp.363-366.

[9]. Kumar Ajay, Singh, B. and Singh, Surinder (2001). Uranium, radium and radon exhalation studies in some soil samples from Una district, Himachal Pradesh, India using track etching technique, Indian Journal of Pure and Applied Physics, 39,pp.761-764.

[10]. Deka P.C., Sarkar Subir,Sarma B.K., Goswami T.D., Ramachandran T.V.,Nambi K.S.V.: Indoor Built Environment,2003:12;343349.

[11]. United Nations Scientific Committee on the Effects of Atomic Radiations (UNSCEAR). Sources and Effects of Ionizing Radiation. UNSCEAR 1993 Report to the General Assembly, with Annexes, New York: United Nations, pp. 73-98. 